\title{
Improving PAI Learning Outcomes Through Peer Lesson Learning Strategies at SDN 92 Kendari
}

\section{Meningkatkan Hasil Belajar PAI Melalui Strategi Pembelajaran Peer Lesson di SDN 92 Kendari}

\author{
Hartin \\ Dinas Pendidikan dan Kebudayaan Kota Kendari \\ Email: Hartin_tina@yahoo.com
}

\begin{abstract}
This article aims to provide an overview of the use of peer lesson type active learning strategies to improve student PAI learning outcomes. The study was conducted in class VA SDN 92 Kendari using a classroom action research approach, carried out in two cycles, where each cycle consisted of 4 meetings. The results showed the low student learning outcomes in the pre-cycle phase. Giving action in cycle 1 and continued in cycle 2 showed a very significant increase in learning outcomes. So it can be concluded that PAI learning outcomes can be improved by using peer lesson learning strategies.
\end{abstract}

\section{Keywords: Active Learning, Peer Lesson, Learning Outcomes}

\section{Abstrak}

Artikel ini bertujuan memberikan gambaran tentang penggunaan strategi pembelajaran aktif tipe peer lesson untuk meningkatkan hasil belajar PAI siswa. Penelitian dilakukan di kelas VA SDN 92 Kendari dengan menggunakan pendekatan penelitian tindakan kelas, dilakukan dalam dua siklus, dimana setiap siklus terdiri dari 4 pertemuan. Hasil penelitian menunjukkan rendahnya hasil belajar siswa pada fase pra siklus. Pemberian tindakan pada siklus 1 dan dilanjutkan pada siklus 2 menunjukkan peningkatan hasil belajar yang sangat signifikan. Sehingga dapat disimpulkan bahwa hasil belajar PAI dapat ditingkatkan dengan menggunakan strategi pembelajarn peer lesson.

Kata Kunci: Pembelajaran Aktif, Peer Lesson, Hasil Belajar 


\section{Pendahuluan}

Hasil belajar peserta didik dapat dipengaruhi oleh beberapa faktor, salah satunya metode mengajar guru (Yasmin \& Santoso, 2019). Metode mengajar guru merupakan faktor eksternal yang secara langsung memengaruhi peserta didik dalam mendapatkan pengetahuan dan pengalaman belajar. Tidak hanya metode mengajar guru, fasilitas belajar dan lingkungan belajar juga adalah faktor eksternal yang dapat memengaruhi hasil belajar (Sholekhah, 2014). Meskipun demikian, secara internal, peserta didik mesti menyiapkan diri agar dapat berjalan beriringan dengan kondisi di luar dirinya, terutama dalam proses pembelajaran. Kemandirian belajar mesti terbangun pada peserta didik yang mengharapkan hasil belajar yang baik (Rijal \& Bachtiar, 2015). Selain itu, aspek-aspek psikologis mesti disiapkan untuk menjalani proses pembelajaran, yaitu sikap, minat dan motivasi belajar (Azis, 2016).

Pada peserta didik di tingkat sekolah dasar, persoalan hasil belajar mereka juga dipengaruhi oleh faktor internal dan eksternal sebagai mana disebutkan di atas. Hasil-hasil riset menunjukkan bahwa hasil belajar anak sekolah dasar dipengaruhi oleh faktor motivasi belajar (Warti, 2016), serta sikap dan minat belajar (Riwahyudin, 2015). Selain itu, faktor kedisiplinan juga menjadi sangat penting dalam rangka perbaikan hasil belajar peserta didik (Elly, 2016).

Paparan temuan di atas, melalui kajian ini akan dilihat secara kontekstual dalam praktik pembelajaran di SDN 92 Kendari. Hasil pengamatan menunjukkan tingkat keaktifan peserta didik dalam proses pembelajaran masih rendah yaitu 55\%. Fakta ini berhubungan dengan peristiwan-peristiwa yang terjadi di dalam kelas misalnya: rendahnya perhatian pada materi pembelajaran, peserta didik kurang menyukai mata pelajaran Pendidikan Agama Islam. Oleh karena itu, penulis berasumsi bahwa kondisi peserta didik tersebut dapat disebabkan oleh metode mengajar guru yang kurang tepat, fasilitas belajar yang belum memadai, media pembelajaran yang tidak menarik, dan tidak adanya perbaikan proses pembelajaran.

Asumsi di atas diturunkan oleh penulis menjadi sebuah langkah strategis yaitu peningkatan hasil belajar PAI melalui penerapan strategi pembelajaran peer lesson. Strategi ini dapat mengaktifkan kinerja otak, perbaikan hasil belajar, tidak mudah melupakan materi pelajaran, menyenangkan, dan otak dapat memproses informasi dengan baik. Hasil-hasil riset menunjukkan 
bahwa strategi pembelajaran peer lesson dapat meningkatkan hasil belajar peserta didik di sekolah dasar (Suketi, 2019). Tidak hanya hasil belajar, strategi pembelajaran peer lesson juga dapat meningkatkan minat belajar (Maisarah, 2015) dan meningkatkan kemampuan berpikir kritis peserta didik (Akbar, 2021).

Penggunaan strategi pembelajaran peer lesson dalam pembelajaran PAI telah dilakukan peneliti sebelumnya, tetapi konteksnya adalah untuk meningkatkan motivasi dan keaktifan belajar (Aziszah, 2019). Selain itu, penerapan strategi peer lesson untuk meningkatkan hasil belajar pada peserta didik di SMAN 1 Gowa (Novitasari, 2021). Oleh karena itu, kajian ini memiliki perbedaan pada aspek kajian dan lokus penelitian.

\section{Metode}

Penelitian ini merupakan penelitian tindakan kelas (classroom action research), yaitu bentuk penelitian kolaboratif untuk memperbaiki kualitas pembelajaran, yang terdiri dari empat langkah pokok yaitu: 1) Perencanaan; (2) tindakan; 3) pengamatan; dan 4) refleksi (Jannah, 2015). Penelitian dilaksanakan di SDN 92 Kendari mulai pada bulan 1 Januari - 26 April 2019. Subjek yang diteliti pada kegiatan penelitian tindakan kelas ini adalah murid kelas VA SDN 92 Kendari tahun pelajaran 2019/2020 dengan jumlah 25. Sedangkan objek dalam penelitian ini adalah penerapan strategi pembelajaran Peer Lesson. Posisi peneliti adalah sebagai pengamat (observer) yang berkolaborasi dengan guru PAI. Tindakan dirancang dalam dua siklus, di mana dalam setiap siklus terdiri dari empat (4) kali pertemuan.

Pada tahap perencanaan dalam penelitian ini, kegiatankegiatan yang dilakukan adalah sebagai berikut:

1. Menyusun rencana pembelajaran

2. Membuat skenario pembelajaran dengan membentuk kelompok kelompok kecil, tiap kelompok beranggotakan 4 (empat) atau 5 (lima) orang dengan penyebaran tingkat kecerdasan.

3. Menentukan alat bantu pelajaran yang menunjang materi pembelajaran.

4. Menentukan kolaborasi dengan teman guru di sekolah sebagai tim peneliti.

5. Membuat/menyusun lembar kerja siswa.

6. Menyusun tes akhir pelajaran. 
Pada tahap tindakan, kegiatan yang dilakukan guru PAI adalah sebagai berikut:

1. Membagi siswa menjadi 6 kelompok kecil sebanyak segmen materi yang akan anda sampaikan.

2. Memberi tugas pada masing-masing kelompok kecil untuk mempelajari satu topik materi.

3. Meminta setiap kelompok menyiapkan materi untuk disampaikan kepada teman-teman sekelas.

4. Meminta satu orang dari setiap kelompok untuk tampil menjadi guru dengan cara mencabut undian.

5. Memberikan kesimpulan dan klarifikasi sekiranya ada yang perlu diluruskan dari pemahaman siswa.

6. Memberikan evaluasi kepada siswa, dengan tujuan untuk mengetahui seberapa besar daya serap dalam proses pembelajaran.

Pengamatan terhadap kegiatan siswa mencakup: a) kehadiran siswa; b) perhatian siswa; c) banyaknya siswa yang bertanya; d) pertanyaan yang disampaikan; e) partisipasi dalam kerjasama kelompoknya. Adapun pengamatan terhadap kegiatan guru mencakup: a) kehadiran guru; b) penampilan di depan kelas; c) cara menyajikan materi pelajaran; d) cara pengelolaan kelas; e) cara penggunaan alat bantu pelajaran; f) penguasaan materi pelajaran; g) suara guru dalam menyampaikan materi pelajaran; h) cara memberi bimbingan kelompok; dan i) waktu yang diperlukan.

Pada tahap refleksi, pengamat dan guru PAI menganalisis hasil kerja siswa, mengevaluasi kegiatan pembelajaran pada siklus I, dan mendiskusikan langkah-langkah perbaikan pada siklus II.

Data yang diperoleh dalam penelitian ini adalah data tes dan non-tes. Alat tes berupa tes tertulis, tes lisan, dan tes perbuatan. Sedangkan alat non-tes berupa angket, observasi, wawancara, dan studi dokumentasi. Data tes berupa lembaran soal tentang materi pelajaran untuk mengetahui hasil belajar siswa. Kemudian data nontes berupa observasi, yaitu lembaran pengamatan aktivitas guru dan aktivitas siswa belajar PAI melalui strategi pembelajaran peer lesson.

Data dikumpulkan melalui observasi dengan menggunakan lembar observasi terhadap kegiatan guru dan siswa. Selanjutnya adalah data yang diperoleh melalui tes hasil belajar yang dilaksanakan pada akhir siklus.

Analisis data penelitian dimulai dengan: menentukan nilai ratarata, menentukan ketuntasan belajar, dan mengetahui peningkatan 
hasil belajar. Menentukan nilai rata-rata dilakukan dengan rumus berikut:

$$
\begin{array}{ll}
\overline{\mathrm{x}}=\frac{\sum x_{1}}{N} & \\
\text { Keterangan : } & \\
\overline{\times} & =\text { nilai rata-rata yang yang diperoleh } \\
\sum x_{1} & =\text { skor semua nilai tiap siswa } \\
N & =\text { jumlah siswa keseluruhan }
\end{array}
$$

Menentukan ketuntasan belajar siswa dilakukan dengan menggunakan rumus berikut:

$$
\mathrm{P}=\sum \frac{F i}{N} X 100 \%
$$

Keterangan :

$\mathrm{P} \quad=$ Presentase peningkatan

$\mathrm{N} \quad=$ Jumlah siswa secara keseluruhan

$\sum \mathrm{Fi}=$ Jumlah siswa pada kategori ketuntasan

Mengetahui peningkatan hasil belajar siswa dilakukan dengan menggunakan rumus berikut:

$$
\mathrm{P}=\frac{\text { Posrate-Basertase }}{\text { Basertase }} \times 100 \%
$$

Keterangan:

$\mathrm{P} \quad=$ jumlah siswa yang tuntas belajar

$\mathrm{N} \quad=$ jumlah siswa secara keseluruhan

$\sum F i=$ jumlah siswa pada kategori ketuntasan.

\section{Hasil Penelitian}

\section{A. Kondisi Hasil Belajar Pra Siklus}

Sebelum pelaksanaan tindakan, peneliti melakukan observasi untuk memperoleh gambaran atau informasi awal mengenai penguasaan materi mata pembelajaran PAI di SDN 92 Kendari. Hasil observasi menunjukan bahwa para siswa mengalami kesulitan dalam memahami materi PAI di sebabkan karena guru mengalami kesulitan untuk menentukan metode atau media yang sesuai dengan karakteristik siswa. Pada observasi awal ini, peneliti melihat bahwa perhatian siswa masih rendah, yang mungkin disebabkan oleh media pembelajaran yang belum bervariatif. Selain itu, kurangnya keteribatan siswa dalam proses pembelajaran menjadi perhatian peneliti. Oleh karena itu, peneliti memberikan tes pra siklus untuk mengetahui kemampuan awal siswa dalam mata pelajaran PAI. 
Tabel 1. Nilai Pra siklus siswa kelas VA SDN 92 Kendari:

\begin{tabular}{|c|c|c|c|}
\hline NO & KODE SISWA & NILAI & KETERANGAN \\
\hline 1 & $\mathrm{~S} 1$ & 80 & Tuntas \\
\hline 2 & S2 & 60 & Tidak Tuntas \\
\hline 3 & S3 & 65 & Tidak Tuntas \\
\hline 4 & S4 & 55 & Tidak Tuntas \\
\hline 5 & S5 & 85 & Tuntas \\
\hline 6 & S6 & 60 & Tidak Tuntas \\
\hline 7 & S7 & 70 & Tidak Tuntas \\
\hline 8 & S8 & 90 & Tuntas \\
\hline 9 & S9 & 87 & Tuntas \\
\hline 10 & S10 & 60 & Tidak Tuntas \\
\hline 11 & S11 & 67 & Tidak Tuntas \\
\hline 12 & S12 & 50 & Tidak Tuntas \\
\hline 13 & S13 & 65 & Tidak Tuntas \\
\hline 14 & S14 & 70 & Tidak Tuntas \\
\hline 15 & S15 & 55 & Tidak Tuntas \\
\hline 16 & S16 & 60 & Tidak Tuntas \\
\hline 17 & S17 & 65 & Tidak Tuntas \\
\hline 18 & S18 & 65 & Tidak Tuntas \\
\hline 19 & S19 & 70 & Tidak Tuntas \\
\hline 20 & S20 & 85 & Tuntas \\
\hline 21 & S21 & 75 & Tuntas \\
\hline 22 & S22 & 65 & Tidak Tuntas \\
\hline 23 & S23 & 60 & Tidak Tuntas \\
\hline 24 & S24 & 80 & Tuntas \\
\hline 25 & S25 & 70 & Tidak Tuntas \\
\hline \multicolumn{2}{|r|}{ JUMLAH } & \multicolumn{2}{|r|}{1714} \\
\hline \multicolumn{2}{|r|}{ RATA-RATA } & \multicolumn{2}{|r|}{69} \\
\hline \multicolumn{2}{|r|}{ TUNTAS } & \multicolumn{2}{|r|}{7} \\
\hline \multicolumn{2}{|c|}{$\begin{array}{l}\text { TIDAK TUNTAS } \\
\end{array}$} & \multicolumn{2}{|r|}{18} \\
\hline \multicolumn{2}{|c|}{ PRESENTASE TUNTAS (\%) } & \multicolumn{2}{|r|}{28} \\
\hline \multicolumn{2}{|c|}{$\begin{array}{c}\text { PRESENTASE TIDAK } \\
\text { TUNTAS }(\%)\end{array}$} & \multicolumn{2}{|r|}{72} \\
\hline
\end{tabular}


Dari 25 siswa, yang memperoleh nilai tuntas hanya 7 siswa atau $28 \%$, sedangkan siswa yang tidak tuntas sebanyak 18 siswa atau sebesar $72 \%$. Hasil ini menandakan perlunya upaya peningkatan hasil belajar, salah satunya dengan melakukan penelitian tindakan kelas melalui strategi pembelajaran peer lesson.

\section{B. Deskripsi Data pada Siklus I}

Siklus I dilaksanakan pada tanggal 7, 14, 21, dan 28 Januari 2019, dengan tahapan sebagai berikut:

\section{Pelaksanaan}

Berdasarkan hipotesis tindakan dan identifikasi masalah, maka peneliti menyusun rencana perbaikan pembelajaran dengan menerapkan strategi Peer Lesson yang bertujuan agar siswa aktif dan paham terhadap materi yang disampaikan, sehingga pembelajaran bisa lebih efektif dan prestasi belajar siswa dapat meningkat. Selanjutnya peneliti bersama guru melakukan langkah - langkah sebagai berikut:

1) Menyusun skenario pembelajaran (RPP) yang memuat serangkaian kegiatan dengan menggunakan strategi Peer Lesson. Materi yang diajarakan adalah tentang PAI. Seluk beluk tentang materi PAI berpedoman apa yang ada dalam silabus mapel Pendidikan Agama Islam kelas VII. RPP digunakan sebagai acuan dalam proses belajar sehingga tidak keluar dari skenaio yang telah ditetapkan.

2) Mempersiapkan alat dan bahan yang digunakan pada kegiatan pembelajaran. Alat yang digunakan adalah berupa kertas pembagian kelompok dalam hal ini kelompok dibagi menjadi 3.Bahan pembelajaran adalah buku materi mapel Pendidikan Agama Islam kelas VII yang diterbitkan oleh Tiga Serangkai.

3) Menyusun soal evaluasi yang akan dipergunakan untuk mengukur prestasi belajar siswa. Dalam penelitian ini evaluasi atau test yang dilaksanakan dengan menggunakan waktu tersendiri. Test yang dilaksanakan pada akhir pembelajaran hanya bersifat test lisan.

4) Mengefektifkan penggunaan strategi mengajar pada setiap siklus. Pengefektifan penggunaan strategi ini dengan dibantu oleh guru mapel yang serumpun, yaitu guru PAI.

2. Tindakan

Pada tahap pelaksanaan tindakan ini, guru melakukan kegiatan pembelajaran yang sudah disusun dalam skenario pembelajaran (RPP). Pada awal pembelajaran guru membuka pelajaran dengan memotivasi dan mengadakan tanya jawab dengan mengajukan beberapa 
pertanyaan yang berhubungan dengan PAI. Setelah guru memberikan gambaran materi yang akan dibahas dan menyampaikan tujuan pembelajaran, guru memberi kesempatan kepada siswa - siswa untuk membaca materi, kemudian guru memberikan penjelasan tentang materi PAI, dan setelah itu guru membagi siswa menjadi tiga kelompok. Setiap kelompok terdiri dari 3-4 orang siswa. Sebelum melakukan kegiatan guru memberikan pengarahan tentang langkahlangkah yang harus ditempuh, yaitu siswa mempelajari materi secara berkelompok. Masing-masing kelompok mempelajari materi yang sudah diberikan oleh guru. Siswa mendalami materi dengan membaca, ada yang mendengarkan penjelasan temannya dalam satu kelompok ada yang mencatat apa yang dijelaskan oleh teman lainnya dalam satu kelompok.

Guru memberi kesempatan kepada siswa untuk bertanya. Beberapa siswa yang belum begitu memahami materi mengajukan pertanyaan, namun ada beberapa siswa yang hanya diam dan terlihat masih bingung. Ada juga beberapa siswa yang terlihat masih malu dalam mengutarakan pertanyaan. Ada juga siswa yang pasif dan kurang konsen pada pembelajaran serta tidak berminat mengikuti pelajaran.

Semua siswa dalam kelompok tersebut terlarut dalam kegiatan masing-masing. Kemudian kelompok maju satu persatu untuk menjelaskan materi yang ia baca kepada kelompok lainnya.

Pada akhir siklus I ini guru memberikan penjelasan dan apresiasi terhadap jawaban siswa-siswa, dan kemudian mengajak siswa untuk menyimpulkan materi pelajaran. Selanjutnya siswa mempersiapkan diri untuk melaksanakan tes formatif yang diberikan oleh guru guna mengetahui tingkat penguasaan materi pelajaran yang baru dibahas di dalam kelas.

Untuk mengukur keberhasilan peserta didik dalam mengikuti proses pembelajaran, maka pada akhir penelitian mengadakan evaluasi. Adapun hasil nilai pada prestasi belajar siklus 1 dapat dilihat pada tabel di bawah ini.

Tabel 2. Nilai Siklus I Siswa Kelas VA SDN 92 Kendari

\begin{tabular}{|c|c|c|c|}
\hline NO & KODE SISWA & NILAI & KETERANGAN \\
\hline 1 & S1 & 80 & Tuntas \\
\hline 2 & S2 & 70 & Tidak Tuntas \\
\hline
\end{tabular}




\begin{tabular}{|c|c|c|c|}
\hline 3 & S3 & 75 & Tuntas \\
\hline 4 & S4 & 65 & Tidak Tuntas \\
\hline 5 & S5 & 85 & Tuntas \\
\hline 6 & S6 & 70 & Tidak Tuntas \\
\hline 7 & S7 & 70 & Tidak Tuntas \\
\hline 8 & S8 & 90 & Tuntas \\
\hline 9 & S9 & 87 & Tuntas \\
\hline 10 & S10 & 70 & Tidak Tuntas \\
\hline 11 & S11 & 80 & Tuntas \\
\hline 12 & S12 & 70 & Tidak Tuntas \\
\hline 13 & S13 & 70 & Tidak Tuntas \\
\hline 14 & S14 & 80 & Tuntas \\
\hline 15 & S15 & 65 & Tidak Tuntas \\
\hline 16 & S16 & 70 & Tidak Tuntas \\
\hline 17 & S17 & 75 & Tuntas \\
\hline 18 & S18 & 75 & Tuntas \\
\hline 19 & S19 & 80 & Tuntas \\
\hline 20 & S20 & 85 & Tuntas \\
\hline 21 & S21 & 80 & Tuntas \\
\hline 22 & S22 & 70 & Tidak Tuntas \\
\hline 23 & S23 & 75 & Tuntas \\
\hline 24 & S24 & 85 & Tuntas \\
\hline 25 & $\mathrm{~S} 25$ & 70 & Tidak Tuntas \\
\hline \multicolumn{2}{|r|}{ JUMLAH } & \multicolumn{2}{|c|}{1892} \\
\hline \multicolumn{2}{|r|}{ RATA-RATA } & \multicolumn{2}{|c|}{75,68} \\
\hline \multicolumn{2}{|c|}{ TUNTAS } & \multicolumn{2}{|c|}{14} \\
\hline \multicolumn{2}{|c|}{ TIDAK TUNTAS } & \multicolumn{2}{|c|}{11} \\
\hline \multicolumn{2}{|c|}{$\begin{array}{c}\text { PRESENTASE } \\
\text { TUNTAS (\%) }\end{array}$} & \multicolumn{2}{|c|}{56} \\
\hline \multicolumn{2}{|c|}{$\begin{array}{c}\text { PRESENTASE TIDAK } \\
\text { TUNTAS }(\%)\end{array}$} & \multicolumn{2}{|c|}{44} \\
\hline
\end{tabular}

Hasil evaluasi di atas menunjukkan bahwa pada pelaksanaan siklus 1 sebanyak 14 siswa atau 56\% yang tuntas, sisanya sebanyak 11 
siswa atau $44 \%$ belum tuntas. Hasil tersebut belum mencapai kriteria ketuntasan kelas yaitu dengan $85 \%$.

3. Observasi

Peneliti sebagai pengamat melakukan pengamatan terhadap jalannya pembelajaran dan keaktifan siswa selama proses kegiatan belajar mengajar. Peneliti melakukan pengamatan terhadap guru dalam menyampaikan materi pembelajaran, strategi yang digunakan, pemberian penguatan, memotivasi siswa dan keterlibatan siswa dalam proses belajar mengajar.

Peneliti juga melakukan pengamatan secara cermat terhadap aktivitas siswa dengan menggunakan Lembar Observasi Siswa yang telah disiapkan terlebih dahulu. Aspek keaktifan meliputi memperhatikan penjelasan guru dengan serius, mengerjakan tugas yang diberikan serta mencatat dan merangkum materi, dan aktif dalam tanya jawab.

4. Refleksi

Berdasarkan hasil observasi dan nilai tes akhir siklus I, ternyata dalam siklus I dengan menggunakan strategi Peer Lesson, proses pembelajaran yang berlangsung mulai terlihat efektif, hal ini ditunjukkan dengan meningkatnya keaktifan peserta didik selama pembelajaran berlangsung, walaupun masih ada beberapa siswa yang masih pasif, tidak memperhatikan penjelasan guru, dan masih banyak siswa yang tidak bertanya saat mengalami kesulitan serta masih malu ketika diminta guru untuk menjadi sebagai sukarelawan untuk membacakan pertanyaan. Hal ini dikarenakan hal-hal sebagai berikut:

a. Siswa belum terbiasa menggunakan strategi Peer Lesson dan masih terpengaruh dengan strategi yang lama

b. Penjelasan guru terlalu cepat

c. Kemungkinan pembagian kelompok terlalu besar, sehingga siswa kurang memahami langkah-langkah dalam mengerjakan soal.

d. Guru dalam hal bertanya kepada siswa dan meminta siswa sebagai sukarelawan kurang merata, sehingga belum semua siswa ikut aktif dalam proses pembelajaran

Karena masih adanya beberapa kekurangan dalam proses pembelajaran pada siklus I ini, maka peningkatan pemahaman siswa belum signifikan. Meskipun demikian, telah ada perbaikan pembelajaran siklus I sebagaimana ditunjukkan pada hasil evaluasi di atas. 
Hasil observasi pada siklus I ditindaklanjuti dengan melakukan refleksi dan mengevaluasi kegiatan yang ada di siklus I, mencari solusi bersama terhadap permasalahan yang ditemukan di kelas dengan melakukan tindakan selanjutnya. Disepakati perlunya meningkatkan cara pembelajaran yang lebih memotivasi siswa sehingga siswa bisa menjadi lebih aktif dalam kegiatan pembelajaran. Dan agar proses pembelajaran dapat berjalan dengan baik dan dapat mencapai indikator keberhasilan, peneliti juga berupaya supaya suasana di dalam kelas menjadi lebih menyenangkan.

Berdasarkan hasil refleksi yang dilakukan peneliti didapatkan beberapa solusi untuk digunakan sebagai rumusan dalam upaya perbaikan terhadap proses pembelajaran pada siklus II dengan strategi Peer Lesson. Upaya- upaya tersebut antara lain sebagai berikut:

1) Menyusun kembali skenario pembelajaran (RPP) dan soal tes untuk siklus II

2) Guru akan menjelaskan lebih pelan

3) Guru akan membagi kelompok siswa lebih kecil, satu kelompok terdiri dari 5 orang sehingga kelompok yang terbentuk lebih banyak (5 Kelompok).

4) Sebaran pertanyaan dan permintaan sebagai sukarelawan kepada siswa akan diusahakan lebih merata, sehingga semua siswa bisa ikut aktif dalam proses pembelajaran.

\section{Deskripsi Data Pelaksanaan Siklus II}

Berdasarkan refleksi pada siklus I, maka pada siklus II peneliti memperbaiki pelaksanaan metode Peer Lesson yang dilaksanakan pada 5, 12, 19, dan 26 Februari 2019 dengan tahapan sebagai berikut:

1. Perencanaan

Dari hasil refleksi siklus I memperlihatkan, bahwa pembelajaran Pendidikan Agama Islam dengan menerapkan model pembelajaran Peer Lessontelah berjalan dengan baik. Hal ini dibuktikan dengan adanya data tentang peningkatan aktivitas dan prestasi belajar siswa, sebagaimana disebutkan di atas. Namun, peningkatan tersebut belum mencapai standar yang ditetapkan, sehingga perlu diadakan perencanaan lanjutan untuk tindakan siklus II.

Pada siklus II ini peneliti membuat rencana perbaikan pembelajaran yang merupakan kelanjutan dari siklus I. Pada siklus II ini peneliti merencanakan akan melaksanakan perbaikan dengan lebih 
mengaktifkan siswa. Peneliti memberikan variasi-variasi kecil agar peserta siswa tidak jenuh dan proses pembalajaran menjadi lebih menarik.

Peneliti menyusun kembali skenario pembelajaran (RPP) dan soal tes siklus II. Peneliti juga akan mengupayakan untuk memberikan penjelasan lebih pelan, serta berusaha untuk lebih menyebarkan pertanyaan kepada siswa dan permintaan kepada siswa untuk menjadi sukarelawan.

2. Tindakan

Pada siklus II ini peneliti lebih menekankan pada penjelasan materi yang masih belum jelas dan siswa yang masih kurang aktif dalam kelompoknya masing-masing. Untuk lebih meningkatkan pemahaman siswa, guru mengadakan tanya jawab dengan siswa tentang materi akhlak tercela. Agar semua siswa aktif dan memperhatikan, guru selalu memberi penjelasan yang mendetail. Siswa yang belum aktif dalam kerja kelompok diberi pengertian dan motivasi agar tidak mengandalkan teman lain yang aktif.

Skenario pembelajaran pada siklus II sama halnya dengan pelaksanaan pembelajaran pada siklus I, hanya saja materi yang disampaikan berbeda dan pembagian anggota setiap kelompoknya lebih sedikit dibanding pada siklus I. Setiap kelompok mendapatkan materi sendiri-sendiri yang sudah dibagi dalam perencanaan. Siswa mulai lebih memahami proses pembelajaran dengan menggunakan strategi ini dikarenakan sudah mengalami pada proses siklus I dan siswa sudah merasakan bahwa strategi yang diterapkan ini memberikan suasana yang berbeda.

Berikut adalah perbandingan nilai yang diperoleh siswa pada siklus II dibanding dengan nilai yang diperoleh siswapada siklus II dapat dilihat dari tabel sebagai berikut:

Tabel 3. Nilai Siklus II Siswa SDN 92 Kendari

\begin{tabular}{|c|c|c|c|}
\hline NO & KODE SISWA & NILAI & KETERANGAN \\
\hline 1 & S1 & 85 & Tuntas \\
\hline 2 & S2 & 80 & Tuntas \\
\hline 3 & S3 & 75 & Tuntas \\
\hline 4 & S4 & 75 & Tuntas \\
\hline 5 & S5 & 85 & Tuntas \\
\hline
\end{tabular}




\begin{tabular}{|c|c|c|c|}
\hline 6 & S6 & 75 & Tuntas \\
\hline 7 & S7 & 75 & Tuntas \\
\hline 8 & S8 & 90 & Tuntas \\
\hline 9 & S9 & 87 & Tuntas \\
\hline 10 & S10 & 80 & Tuntas \\
\hline 11 & S11 & 80 & Tuntas \\
\hline 12 & S12 & 80 & Tuntas \\
\hline 13 & S13 & 85 & Tuntas \\
\hline 14 & S14 & 80 & Tuntas \\
\hline 15 & S15 & 70 & Tidak Tuntas \\
\hline 16 & S16 & 80 & Tuntas \\
\hline 17 & S17 & 75 & Tuntas \\
\hline 18 & S18 & 75 & Tuntas \\
\hline 19 & S19 & 80 & Tuntas \\
\hline 20 & S20 & 85 & Tuntas \\
\hline 21 & S21 & 80 & Tuntas \\
\hline 22 & S22 & 80 & Tuntas \\
\hline 23 & S23 & 75 & Tuntas \\
\hline 24 & S24 & 85 & Tuntas \\
\hline 25 & S25 & 75 & Tuntas \\
\hline \multicolumn{2}{|c|}{ JUMLAH } & \multicolumn{2}{|c|}{1992} \\
\hline \multicolumn{2}{|c|}{ RATA-RATA } & \multicolumn{2}{|c|}{79,68} \\
\hline \multicolumn{2}{|c|}{ TUNTAS } & \multicolumn{2}{|c|}{24} \\
\hline \multicolumn{2}{|c|}{ TIDAK TUNTAS } & \multicolumn{2}{|c|}{1} \\
\hline \multicolumn{2}{|c|}{$\begin{array}{c}\text { PRESENTASE TUNTAS } \\
(\%)\end{array}$} & \multicolumn{2}{|c|}{96} \\
\hline \multicolumn{2}{|c|}{$\begin{array}{c}\text { PRESENTASE TIDAK } \\
\text { TUNTAS }(\%)\end{array}$} & \multicolumn{2}{|c|}{4} \\
\hline
\end{tabular}

Hasil evaluasi menunjukkan bahwa pada pelaksanaan siklus II, 24 siswa atau 96\% yang telah mencapai nilai KKM. Sedangkan 1 peserta didik atau $4 \%$ belum mencapai nilai KKM. Hal tersebut sudah melampaui kriteri ketuntasan kelas (kriteria minimal 85\%, sedangkan hasil siklus 2 mencapai 96\%). 


\section{Observasi}

Dari pengamatan peneliti selama proses pembelajaran siklus II diperoleh sebagai berikut:

a. Guru sudah mampu menerapkan metode Peer Lesson dengan baik dalam proses pembelajaran.

b. Guru menjelaskan materi dengan baik.

c. Guru sudah menguasai kelas dengan baik.

4. Refleksi

Berdasarkan data yang didapat dari pelaksanaan siklus II menunjukkan adanya peningkatan yang sangat signifikan yaitu aktivitas, dan prestasi belajar peserta didik. Hal ini diawali dengan selama proses pembelajaran Pendidikan Agama Islam dengan penerapan model pembelajaran Peer Lesson antusias siswa dalam mengikuti kegiatan belajar mengajar. Dalam penelitian perbaikan pembelajaran ini, sudah tuntas secara klasikal dan sudah nampak adanya peningkatan semangat dan keseriusan siswa dalam mengikuti pelajaran. Menurut pengamat, semua siswa sudah cocok dengan strategi Peer Lesson. Hasil observasi terhadap aktivitas belajar siswa menunjukkan peningkatan dari siklus I. Sedangkan ketuntasan belajar siswa pada siklus II ini secara klasikal pencapaian 96\% peserta didik yang didapat dari hasil tes lisan maupun tulisan. Dengan demikian peneliti menganggap peningkatan sudah baik dengan menyisakan satu peserta didik yang belum tuntas sehingga peneliti menghentikan penelitian ini.

Partisipasi siswa dalam pembelajaran agak baik dibandingkan sebelum dilakukan penilaian perbaikan pembelajaran. Siswa sangat tertarik dengan strategi mengajar guru. Namun ada beberapa siswa yang masih takut untuk bertanya saat mengalami kesulitan, dan masih belum aktif mengerjakan tugas yang diberikan oleh guru hal ini sangat berdampak pada prestasi siswa ketika guru masih menggunakan strategi konvesional.

Semangat siswa dalam perbaikan pembelajaran masih rendah, banyak siswa yang kurang memperhatikan arahan guru. Dari hasil penelitian di akhir perbaikan pembelajaran siklus I walaupun masih ada beberapa siswa yang belum mencapai ketuntasan yaitu 5 anak sehingga ketuntasan secara klasikal hanya mencapai $58.33 \%$ sedangkan ketuntasan minimal secara klasikal yang harus dicapai adalah $80 \%$, namun dari data terlihat sudah ada peningkatan prestasi siswa pada siklus I dibandingkan sebelum perbaikan. Prosentase 
peningkatan prestasi masing - masing siswa pada siklus I dibandingkan dengan pada pre-test.

Untuk pelaksanaan siklus II, guru lebih memotivasi dan memacu siswa untuk memperhatikan setiap langkah yang ada dalam strategi Peer Lesson sehinggga siswa paham dan pada akhirnya semua siswa bisa menikmati dan merasa senang dengan strategi Peer Lesson ini dan siswa pun menjadi lebih aktif dalam proses pembelajaran. Langkah langkah perbaikan tindakan yang dilakukan pada pembelajaran siklus II ini memberi dampak yang positif pada peningkatan prestasi siswa.

Ada peningkatan keseriusan siswa dalam pembelajaran. Semua siswa mengerjakan tugas guru. Semangat siswa mulai meningkat sehingga siswa berusaha untuk memperhatikan penjelasan tentang materi. Siswa pun pada akhirnya dapat melakukan kerja strategi Peer Lessondengan mandiri tanpa bantuan guru dan guru hanya membimbing seperlunya saja.

Keterlibatan siswa dalam pembelajaran siklus II mengalami peningkatan dibanding siklus I. Dari hasil penelitian pada pembelajaran siklus II ini terlihat adanya peningkatan prestasi dibandingkan perbaikan pembelajaran sebelumnya (siklus I). Rata-rata ketuntasan klasikal 96\% sehingga ketuntasan klasikal sudah tercapai karena ketuntasannya sudah lebih dari $80 \%$. Untuk prosentase peningkatan prestasi siswa dari pembelajaran siklus I ke pembelajaran siklus II. Penggunaan strategi Peer Lessonyang melibatkan siswa dapat meningkatkan pemahaman siswa terhadap materi pelajaran sehingga nilai hasil belajar meningkat. Pada pelaksanaan siklus I dan siklus II dapat diketahui adanya perubahan - perubahan, baik dari cara belajar siswa maupun peningkatan prestasi siswa dengan proses pembelajaran yang menggunakan strategi Peer Lesson. Hal ini membuktikan bahwa strategi Peer Lessondapat meningkatkan prestasi siswa dalam proses pembelajaran.

\section{Pembahasan}

\section{A. Strategi Pembelajaran Peer Lesson dan Perbaikan Hasil Belajar PAI}

Hasil belajar peserta didik dalam mata pelajaran PAI menunjukkan tingkat pemahaman dan pengetahuan mereka tentang agama Islam berdasarkan jenjang pendidikannya masing-masing. Upaya meningkatkan hasil belajar harus dilakukan secara berkelanjutan karena hal ini berkaitan dengan kehidupan beragama 
peserta didik di masa depan. Karenanya, pembelajaran pendidikan agama Islam harus dapat dilakukan secara sistematis dan terorganisir. Melihat pembelajaran pendidikan agama Islam sebagai sebuah sistem (Samrin, 2015).

Upaya perbaikan hasil belajar PAI dengan menggunakan strategi pembelajaran peer lesson terus berkembang pada berbagai tema-tema spesifik seperti ketentuan shalat (Nurjannah, 2020). Topik spesifik lainnya adalah dalam pembelajaran ilmu tajwid, dimana strategi pembelajaran peer lesson cukup efektif dalam perbaikan hasil belajar (Zakirochman, 2020). Strategi ini dapat digunakan pada berbagai jenjang pendidikan.

Langkah-langkah pelaksanaan strategi PeerLeasson adalah : 1) Bagilah siswa menjadi sub-sub kelompok. Buatlah sub-sub kelompok dengan jumlah yang sesuai dengan topik yang akan diajarkan; 2) Tiap kelompok kecil diberi tugas untuk mempelajari satu topik materi, kemudian mengajarkannya kepada kelompok lain; 3) Minta tiap kelompok untuk menyusun cara dalam menyajikan atau mengajarkan topik mereka kepada siswa lain. Sarankan kepada mereka untuk menghindari cara mengajar sistem ceramah atau semacam pembacaan laporan. Doronglah mereka untuk menjadikan pengalaman belajar sebagai pengalaman yang aktif bagi siswa; 4) Sediakan media visual; 5) Siapkan media pengajaran yang diperlukan; 6) Menggunakan contoh-contoh yang relevan; 7) Melibatkan teman dalam proses pembelajaran, misalnya melalui diskusi, permainan, kuis, studi kasus, dan lain-lain; 8) Memberi kepada yang lain untuk bertanya; 9) Beri siswa waktu yang cukup untuk persiapan, baik di dalam maupun di luar kelas; 10) Setiap kelompok menyampaikan materi sesuai tugas yang telah diberikan; 11) Setelah semua kelompok melaksanakan tugas, beri kesimpulan dan klarifikasi sekiranya ada yang perlu diluruskan dari pemahaman siswa (Syarifah, 2014).

Strategi pembelajaran peer lesson memiliki manfaat penting dalam perkembangan peserta didik, yaitu: 1) Otak bekerja secara aktif. Dengan strategi Peer Lesson siswa diajak secara aktif baik didalam maupun diluar kelas, mereka diberi kesempatan untuk memilih starategi apa yang mereka inginkan dan meraka juga mempunyai tanggung jawab menguasai pembelajaran untuk di presentasikan atau di ajarkan kepada temannya. Ketika peserta didik belajar dengan aktif, berarti mereka mendominasi aktivitas 
pembelajaran. Dengan ini mereka secara aktif menggunakan otak, baik untuk menemukan ide pokok dari materi pelajaran, memecahkan persoalan atau mengaplikasikan apa yang baru mereka pelajari kedalam persoalan yang ada dalam kehidupan nyata; 2) Hasil belajar yang maksimal. Dengan strategi Peer Lesson peserta didik dapat belajar secara aktif, di dalam dan di luar kelas dan mereka mempunyai tanggung jawab untuk mendiskusikan dan mengajarkan materi pembelajaran kepada teman yang lain, sehingga mendorongmereka untuk lebih giat belajar baik secara mandiri maupun kelompok. Dengan demikian hasil belajar akan lebih maksimal: 3) Tidak mudah melupakan materi pembelajaran. Ketika peserta didik pasif atau hanya menerima dari guru, ada kecenderungan untuk cepat melupakan apa yang telah diberikan, dan starategi Peer Lesson ini siswa diajak serta untuk aktif dalam prosespembelajaran baik didalam maupun di luar kelas. Dengan demikian akan membuahkan hasil belajar yang langgeng; 4) Proses pembelajaran yang menyenangkan. Strategi Peer Lesson merupakan starategi pembelajaran mengajak siswa untuk belajar secara aktif. Dengan belajar aktif ini peserta didik diajak untuk turut serta dalam semua proses pembelajaran, tidakhanya mental tetapi juga melibatkan fisik. Dengan cara ini biasanya peserta didik akan merasakan suasana yang menyenangkan. Otak tidak akan dapat memproses informasi yang masuk kalau otak itu tidak dalam kondisi hidup, maka otak memerlukan sesuatu yang dapat dipakai untuk menghubungkan antara informasi yang baru diajarkan dengan informasi yang telah dimiliki. Jika belajar itu pasif, otak tidak akan dapat menghubungkan antara informasi yang baru dengan informasi yang lama. Selanjutnya otak perlu beberapa langkah untuk menyimpan informasi. Langkahlangkah itu bisa berupa pengulangan informasi, mempertanyakan informasi atau mengajarkannya kepada orang (Lubis, 2019).

\section{B. Peran Guru Dalam Peningkatan Hasil Belajar}

Guru merupakan faktor penentu dalam transfer pengetahuan kepada peserta didik (Kirom, 2017). Tidak hanya pengetahuan, tetapi juga menyangkut aspek psikologis peserta didik seperti sikap, hingga psikomotorik (Juhji, 2016). Dengan demikian, dapat dikatakan bahwa guru adalah penghantar utama pengetahuan dan pengalaman belajar kepada peserta didik. Karenanya, seorang guru harus mengembangkan kompetensi secara terus-menerus agar peranya 
selalu relevan dengan perkembangan terbaru. Upaya tersebut akan berdampak pada peningkatan kinerjanya (Putri \& Imaniyati, 2017).

Guru memiliki semesta yang sangat luas, tidak hanya memahami tugas pokoknya dalam praktik pembelajaran, tetapi memahami berbagai dimensi pengelolaan pembelajaran, termasuk relevansi dengan perkembangan teknologi (Samrin \& Syahrul, 2021). Praktik pembelajaran yang selaras dengan semangat era 4.0 perlu menjadi perhatian guru, sehingga peningkatan kualifikasi adalah menjadi tuntutan (Miarso, 2008). Guru tidak dapat bertahan pada kebiasaan lama, tetapi harus adaptif, menerima perubahan, dengan menerapkan model belajar yang lebih dinamis seperti blended learning. Cara ini dapat menjembatani berbagai keterbatasan pembelajaran, termasuk transisi guru dari dari lama ke pembelajaran abad 21 (Wardani, Toenlioe \& Wedi, 2018).

Kesadaran guru sebagai fasilitator dan motivator pembelajaran harus terjaga dan ditingkatkan (Purwaningsih, 2016). Penguasaan keterampilan mengajar sesuai semangat zaman, sebagaimana dijelaskan di atas akan memudahkan guru menjalankan tugas-tugasnya. Demikian pula upaya secara serius untuk memahami dimensi-dimensi kepesertadidikan akan memudahkan guru dalam memberi bantuan kepada peserta didik.

Sejalan dengan pemberlakuan kurikulum 2013 yang bersemangat saintifik, maka praktik pembelajaran juga mesti memperlihatkan interaksi edukatif yang ilmiah. Tidak sebatas pada pembelajaran di kelas, tetapi guru harus mulai mengembangkan pembelajaran berbasis riset, misalnya menguji coba stategi pembelajaran terbaru atau menggunakan penelitian tindakan kelas (Sabdah, 2019).

\section{Pentingnya Lingkungan Belajar}

Hasil belajar tidak hadir pada ruang kosong. Disamping peran guru, lingkungan belajar juga mesti dikondisikan untuk mendukung proses pembelajaran. Lingkungan belajar mencakup lingkungan keluarga di rumah dan lingkungan sekolah. Riset-riset menunjukkan bahwa lingkungan belajar memiliki pengaruh kuat terhadap hasil belajar (Sholihah \& Kurniawan, 2016). Artinya lingkungan belajar yang baik akan menciptakan suasana nyaman bagi peserta didik untuk belajar, sehingga berdampak pada hasil belajar yang baik pula. 
Lingkungan belajar di rumah akan tercipta jika mendapat dukungan orang tua, tidak hanya tersedianya fasilitas pembelajaran yang dibutuhkan, tetapi juga suasana rumah yang mendorong untuk belajar (Afriansyah, Dadi \& Hasnawati, 2014). Perhatian orang tua akan menjadi energi positif bagi peserta didik untuk menunjukkan yang terbaik dalam pembelaran, terutama peningkatan hasil belajar (Mahmudi, Sulianto \& Listyarini, 2020). Dukungan orang tua dapat juga ditunjukkan dengan penerapan disiplin belajar di rumah (Purbiyanto \& Rustiana, 2018).

Lingkungan belajar di sekolah mesti disiapkan untuk mendukung peningkatan hasil belajar peserta didik. Di samping peran guru, dalam konteks yang lebih besar, desain sekolah mesti mengarah pada dukungan praktik pembelajaran. Karenanya, kepemimpinan sekolah harus menunjukkan komitmen yang kuat untuk perbaikan secara terus-menerus dan membuka ruang untuk inovasi-inovasi yang berasal dari warga sekolah (Syahrul, 2015). Kebijakan-kebijakan yang sejalan dengan semangat era 4.0 mesti dilahir oleh pimpinan sekolah, misalnya pengembangan website sekolah untuk kegiatan pembelajaran (Laugi, 2020). Bagi kepala sekolah, keberadaan website sekolah tidak hanya dapat bermanfaat dalam rangka supervisi manajerial, tetapi juga supervisi akademik untuk meningkatkan kinerja guru (Syahrul at al, 2019).

Membangun disiplin peserta didik menjadi bagian penting dalam desain pengelolaan sekolah, melalui penegakkan tata tertib sekolah (Laugi, 2019). Penegakkan tata tertib tidak hanya dimaknai sebagai peristiwa hokum semata, tetapi dalam rangka membangun kebiasaan yang baik bagi peserta didik. Tentu saja penegakkan tata tertib sekolah akan berjalan secara efektif jika didukung oleh teladan yang baik dari pimpinan dan guru.

\section{Penguatan Dimensi Internal Peserta Didik}

Dimensi psikologis yang dimaksud mencakup: sikap, motivasi, minat, kemandirian belajar, gaya belajar dan spritualitas peserta didik. Sikap terhadap belajar akan memengaruhi hasil belajar peserta didik. Hasil-hasil riset menunjukkan bahwa semakin tinggi sikap peserta didik maka semakin tinggi pula hasil belajar. Demikian pula sebaliknya (Nugraha, 2015). Sikap terhadap belajar bagi peserta didik akan muncul dalam pernyataan verbal yang bersifat kognitif misalnya "pelajaran PAI bagus", selanjutnya akan muncul pernyataan 
sikap "saya menyukai pelajaran PAI", dan diakhiri dengan perilaku "saka akan mengikuti pelajaran PAI dengan tekun".

Motivasi belajar peserta didik dapat bersifat internal maupun eksternal. Secara internal motivasi ini dapat dilihat sebagai tingkat kesadaran yang tinggi tentang penting belajar bagi peserta didik. Akan tetapi motivasi internal ini hanya ditemukan pada peserta didik tertentu saja, atau dapat dikatakan jarang ditemukan. Karenanya, yang dominan muncul adalah motivasi ekstrinsik yaitu kemauan belajar yang disebabkan oleh faktor-faktor di luar diri peserta didik. Karenanya, dukungan lingkungan belajar baik di rumah maupun sekolah, sebagaimana telah dijelaskan di atas, mesti dapat direalisasikan. Hasil riset menunjukkan bahwa motivasi dalam berbagai bentuknya (contoh: motivasi belajar, motivasi berprestasi) memiliki pengaruh yang kuat dalam memperbaiki hasil belajar (Suprapto, 2015; Nurmala at al, 2014).

Minat merupakan keinginan seseorang terhadap sesuatu. Jika konteksnya adalah belajar maka minat belajar dapat dipahami sebagai keinginan peserta didik untuk belajar. Dari sini terlihat bahwa hasil belajar sebagai salah satu tujuan dalam pembelajaran, cukup dekat dengan minat belajar. Artinya, jika peserta didik memiliki keinginan kuat untuk belajar maka hal itu akan menghantarkannya pada capaian belajar yang baik. Hasil riset menunjukkan bahwa minat belajar memiliki pengaruh kuat terhadap hasil belajar (Lestari, 2015). Bahkan, minat belajar menjadi faktor penentu dalam tinggi atau rendahnya hasil belajar peserta didik (Nurhasanah \& Sobandi, 2016).

Kemandirian belajar menunjukkan tingkat kesediaan peserta didik untuk belajar tanpa paksaan. Hal ini tidak terbentuk dengan sendirinya, tetapi melalui proses latihan sehingga terbangun kebiasaan untuk belajar secara mandiri. Kondisi ini menunjukkan tingkat kedewasaan peserta didik untuk mengatur sendiri berbagai kegiatan belajarnya. Hal ini terkait juga dengan persoalan kedisiplinan sebagaimana telah disinggung sebelumnya. Hasil riset menguatkan bahwa kemandirian belajar memiliki pengaruh yang kuat terhadap hasil belajar (Bungsu at al, 2019).

Gaya belajar dianggap sebagai cara yang disukai dalam berpikir, memproses dan memahami informasi (Haviz, 2020). Artinya, peserta didik dapat memilih cara terbaik yang dianggap nyaman untuk belajar. Namun hal ini lebih mungkin dilakukan di rumah. Tentu sekolah perlu memikirkan hal ini pula, agar peserta 
didik dapat memilih cara terbaik untuk belajar. Hasil riset menunjukkan bahwa gaya belajar memiliki implikasi besar dalam pembelajaran (Zagoto at al, 2019), utamanya pada peningkatan hasil belajar (Syofyan, 2018).

Spritualitas merupakan gambaran tentang pencerahan diri ataupun makna hidup, yang biasanya mengarah pada tujuan hidup. Spritualitas memang mengarah pada kepribadian dewasa, stabil, tidak lagi mudah dipengaruhi oleh faktor-faktor eksternal. Meskipun spritualitas ini mengarah pada orang-orang dewasa, akan tetapi hal ini perlu dilatih sejak dini melalui pengenalan makna dan tujuan hidup. Termasuk dalam hal ini adalah penekanan bahwa belajar adalah salah satu cara untuk mencapai pencerahan. Misalnya dengan mengenalkan doktrin keagamaan tentang pentingnya membaca atau belajar, bagi laki-laki dan perempuan, sejak buaian hingga ke liang lahat. Hasil riset menunjukkan bahwa spritualitas peserta didik memengaruhi perilaku belajar (Mbeo \& Kuanine, 2020) serta motivasi dan prestasi belajar (Fitrio at al, 2020).

\section{Kesimpulan dan Implikasi}

Berdasarkan hasil dan pembahasan penelitian menegaskan bahwa hasil belajar PAI dapat ditingkatkan dengan menerapkan strategi pembelajaran peer lesson. Hasil belajar dapat ditingkatkan dengan memaksimalkan peran guru, mendesain lingkungan belajar yang kondusif, dan menguatkan dimensi-dimensi internal peserta didik. Kajian ini merekomendasikan perlunya komunitas guru yang focus pada perbaikan hasil belajar peserta didik, dan fokus pula peningkatan kompetensi ke-PAI-an. Perlunya kebijakan sekolah yang mendukung inovasi dari guru dan kebijakan yang memungkinkan peserta didik dapat memilih gaya belajar tertentu. 


\section{Daftar Pustaka}

Afriansyah, D., Dadi, S., \& Hasnawati, H. (2014). HUBUNGAN ANTARA DUKUNGAN ORANG TUA DENGAN HASIL BELAJAR SISWA PADA PEMBELAJARAN IPS DIKELAS VI SD NEGERI 68 KOTA BENGKULU (Doctoral dissertation, Universitas Bengkulu).

Akbar, A. (2021). engaruh Penerapan Strategi Pembelajaran Aktif Peer Lessons Terhadap Kemampuan Berfikir Kritis Siswa Pada Mata Pelajaran Tematik Kelas V di Sekolah Dasar Negeri 001 Salo Timur Kecamatan Salo Kabupaten Kampar (Doctoral dissertation, UNIVERSITAS ISLAM NEGERI SULTAN SYARIF KASIM RIAU).

Bungsu, T. K., Vilardi, M., Akbar, P., \& Bernard, M. (2019). Pengaruh Kemandirian Belajar Terhadap Hasil Belajar Matematika Di Smkn 1 Cihampelas. Journal on Education, 1(2), 382-389.

Azis, P. A. (2016). Hubungan minat, motivasi belajar dan sikap dengan hasil belajar siswa kelas viii smp negeri 13 makassar. Journal of EST, 2(3), 144-151.

Aziszah, S. R. (2019). PENGARUH PENERAPAN STRATEGI PEMBELAJARAN AKTIF PEER LESSON TERHADAP MOTIVASI DAN KEAKTIFAN BELAJAR MATA PELAJARAN PENDIDIKAN AGAMA ISLAM (STUDY QUASI EXPERIMENTAL) DI SMPN 1 NGANTRU TULUNGAGUNG.

Elly, R. (2016). Hubungan kedisiplinan terhadap hasil belajar siswa kelas v di sd negeri 10 banda aceh. Jurnal Pesona Dasar, 3(4).

Fitrio, T., Utami, S., Sobar, M. W. I., \& Fitri, R. R. (2020). MENINGKATKAN SPIRITUALITAS, MOTIVASI DAN PRESTASI BELAJAR MAHASISWA SEKOLAH TINGGI ILMU EKONOMI INDRAGIRI (STIE-I) RENGAT. VALUES: Jurnal Pengabdian kepada Masyarakat, 2(1), 59-62.

Haviz, M. (2020). Hubungan gaya belajar dengan hasil belajar siswa pada pembelajaran biologi kelas X SMAN 2 Sungai Tarab Kabupaten Tanah Datar. 
Jannah, F. (2015). Inovasi Pendidikan Dalam Rangka Peningkatan Kualitas Pembelajaran Melalui Penelitian Tindakan Kelas. -, l(1).

Juhji, J. (2016). Peran Urgen Guru dalam Pendidikan. Studia Didaktika, 10(01), 51-62.

Kirom, A. (2017). Peran guru dan peserta didik dalam proses pembelajaran berbasis multikultural. Jurnal Al-Murabbi, 3(1), 69-80.

Laugi, S. (2019). Penerapan tata tertib sekolah untuk membangun disiplin siswa di SMA Negeri 1 Konawe. Shautut Tarbiyah, 25(2), 239-258.

Laugi, S. (2020). Use of Websites in School Management: An Effort to Build School Readiness in the Era of 4.0. Shautut Tarbiyah, 26(2), 174-191.

Lestari, I. (2015). Pengaruh waktu belajar dan minat belajar terhadap hasil belajar matematika. Formatif: Jurnal Ilmiah Pendidikan MIPA, 3(2).

Lubis, R. U. (2019). Pengaruh Penggunaan Strategi Peer Lesson terhadap Kemampuan Menganalisis Isi, Sistematika, dan Kaidah Kebahasaan Proposal Kegiatan oleh Siswa Kelas XI SMA Negeri 10 Medan Tahun Pembelajaran 2018/2019 (Doctoral dissertation, Universitas Negeri Medan).

Mahmudi, A., Sulianto, J., \& Listyarini, I. (2020). Hubungan Perhatian Orang Tua Terhadap Hasil Belajar Kognitif Siswa. Jurnal Pedagogi dan Pembelajaran, 3(1), 122-129.

Maisarah, M. (2015). UPAYA MENINGKATKAN MINAT BELAJAR DAN HASIL BELAJAR SISWA MELALUI PENERAPAN STRATEGI PEER LESSON DI KELAS V SD NEGERI 34 BANDA ACEH TAHUN PELAJARAN 2013/2014. JURNAL TEMATIK, 5(01).

Mbeo, D., \& Kuanine, M. H. (2020). Pengaruh Spiritualitas Terhadap Perilaku Belajar Siswa. SESAWI: Jurnal Teologi dan Pendidikan Kristen, 1(2), 91-103.

Miarso, Y. (2008). Peningkatan kualifikasi guru dalam perspektif teknologi pendidikan. Jurnal Pendidikan Penabur, 7(10), 6676.

Novitasari, R. (2021). Efektivitas Penerapan Strategi Pembelajaran Aktif Berbasis Peer Lesson Terhadap Hasil Belajar Pendidikan Agama Islam Peserta Didik Kelas XI MIA 2 di 
SMAN 1 Gowa (Doctoral dissertation, Universitas Islam Negeri Alauddin Makassar).

Nugraha, U. (2015). Hubungan Persepsi, Sikap Dan Motivasi Belajar Terhadap Hasil Belajar Pada Mahasiswa Pendidikan Olahraga Dan Kesehatan Universitas Jambi. Cerdas Sifa Pendidikan, 4(1).

Nurhasanah, S., \& Sobandi, A. (2016). Minat belajar sebagai determinan hasil belajar siswa. Jurnal Pendidikan Manajemen Perkantoran (JPManper), 1(1), 128-135.

Nurjannah, N. (2020). Meningkatkan Hasil Belajar Mata Pelajaran Pendidikan Agama Islam Pokok Bahasan Mengenal Ketentuan Shalat dengan Menggunakan Strategi Peer Lesson pada Siswa Kelas IV SDN Malei Tojo. Jurnal Paedagogy, 7(2), 90-96.

Nurmala, D. A., Tripalupi, L. E., \& Suharsono, N. (2014). Pengaruh motivasi belajar dan aktivitas belajar terhadap hasil belajar akuntansi. Jurnal Pendidikan Ekonomi Undiksha, 4(1).

Purbiyanto, R., \& Rustiana, A. (2018). Pengaruh Disiplin Belajar, Lingkungan Keluarga, dan Motivasi Belajar Terhadap Hasil Belajar Siswa. Economic Education Analysis Journal, 7(1), 341-361.

Purwaningsih, E. (2016). Peranan Guru Sebagai Fasilitator dan Motivator dalam Meningkatkan Hasil Belajar di Kelas XI Smk. Jurnal Pendidikan dan Pembelajaran Khatulistiwa, $5(10)$.

Putri, A. D. K., \& Imaniyati, N. (2017). Pengembangan profesi guru dalam meningkatkan kinerja guru (Professional development of teachers in improving the performance of teacher). Jurnal Pendidikan Manajemen Perkantoran, 2(2), 93-101.

Rijal, S., \& Bachtiar, S. (2015). Hubungan antara sikap, kemandirian belajar, dan gaya belajar dengan hasil belajar kognitif siswa. Jurnal Bioedukatika, 3(2), 15-20.

Riwahyudin, A. (2015). Pengaruh sikap siswa dan minat belajar siswa terhadap hasil belajar IPA siswa kelas V sekolah dasar di Kabupaten Lamandau. Jurnal pendidikan dasar, 6(1), 11-23.

Sabdah, S. (2019). Desain Penelitian Tindakan Kelas Berbasis Pembelajaran Kooperatif Tipe Teams Game Tournament. Shautut Tarbiyah, 25(1), 135-158.

Samrin, S. (2015). Dasar Perencanaan Sistem Pembelajaran Pendidikan Agama Islam. Shautut Tarbiyah, 21(1), 128-144. 
Samrin, M. P. I., \& Syahrul, S. P. I. (2021). Pengelolaan Pengajaran. Deepublish.

Sholekhah, I. M. (2014). Pengaruh Fasilitas Belajar dan Lingkungan Keluarga terhadap Hasil Belajar IPS Terpadu melalui Motivasi Belajar SMP Negeri 1 Ambarawa (Studi Kelas VII Tahun Ajaran 2013/2014). Economic Education Analysis Journal, $3(2)$.

Sholihah, A., \& Kurniawan, R. Y. (2016). Analisis Pengaruh Motivasi Belajar Dan Lingkungan Belajar Terhadap Hasil Belajar. Jurnal Pendidikan Ekonomi (JUPE), 4(3).

Suketi, E. (2019). Penerapan Metode Pembelajaran Peer Lesson Untuk Meningkatkan Hasil Belajar Pkn Siswa Kelas 6 Sd Negeri Tonjong 1 Kota Sukabumi. Jurnal Perseda: Jurnal Pendidikan Guru Sekolah Dasar, 2(2), 15-31.

Suprapto, E. (2015). Pengaruh model pembelajaran kontekstual, pembelajaran langsung dan motivasi berprestasi terhadap hasil belajar kognitif. invotec, 11(1).

Syahrul, S. (2015). Kepemimpinan dan Inovasi Lembaga Pendidikan (Pengalaman Pondok Gontor VII Putra Sulawesi Tenggara). Al-TA'DIB: Jurnal Kajian Ilmu Kependidikan, 8(1), 82-100.

Syahrul, S., Alim, N., Pairin, P., \& Nur, J. (2019). Utilization of management information systems in managerial supervision at IAIN Kendari. International Journal of Recent Technology and Engineering (TM), 8(1C2), 392-392.

Syarifah, S. (2014). Peningkatan keterampilan membaca dan menulis melalui media flashcard dan metode peer lesson di kelas III MI Sambongsari Weleri Kendal tahun 2014 (Doctoral dissertation, UIN Walisongo).

Syofyan, H. (2018). Analisis gaya belajar dan motivasi berprestasi terhadap hasil belajar IPA. Jurnal Eduscience, 3(2), 76-85.

Wardani, D. N., Toenlioe, A. J., \& Wedi, A. (2018). Daya tarik pembelajaran di era 21 dengan Blended Learning. Jurnal Kajian Teknologi Pendidikan, 1(1), 13-18.

Warti, E. (2016). Pengaruh motivasi belajar siswa terhadap hasil belajar matematika siswa di SD Angkasa 10 Halim Perdana Kusuma Jakarta Timur. Mosharafa: Jurnal Pendidikan Matematika, 5(2), 177-185.

Yasmin, Z., \& Santoso, B. (2019). Fasilitas belajar dan metode mengajar guru sebagai faktor yang mempengaruhi hasil belajar 
peserta didik. Jurnal Pendidikan Manajemen Perkantoran (JPManper), 4(1), 134-140.

Zagoto, M. M., Yarni, N., \& Dakhi, O. (2019). Perbedaan Individu dari Gaya Belajarnya Serta Implikasinya Dalam Pembelajaran. Jurnal Review Pendidikan dan Pengajaran, 2(2), 259-265.

Zakirochman, M. (2020). PENINGKATAN HASIL BELAJAR PENDIDIKAN AGAMA ISLAM MATERI ILMU TAJWID DENGAN METODE PEER LESSON PADA SISWA KELAS VII SMP ISLAM SARBINI GRABAG KABUPATEN MAGELANG TAHUN PELAJARAN 2019-2020. 